\title{
CHARACTERIZATION OF THE RHODOCOCCUS SP. MK1 STRAIN AND ITS PILOT APPLICATION FOR BIOREMEDIATION OF DIESEL OIL-CONTAMINATED SOIL
}

\author{
ÁgNes Erdeiné Kis ${ }^{1,2,3}$, KrisZtián LaCZi ${ }^{1}$, SZILVIa Zsíros ${ }^{1}$, PÉTER Kós ${ }^{1,4}$, \\ ROLAND TENGÖLICS ${ }^{1}$, NAILA BOUNEDJOUM ${ }^{1}$, TAMÁS KOVÁCS ${ }^{5}$, \\ GÁBOR RÁKHELY ${ }^{1,2,3}$ and KATALIN PEREI ${ }^{1,3 *}$ \\ ${ }^{1}$ Department of Biotechnology, University of Szeged, Szeged, Hungary \\ ${ }^{2}$ Institute of Biophysics, Biological Research Centre Hungarian Academy of Sciences, \\ Szeged, Hungary \\ ${ }^{3}$ Institute of Environmental and Technological Sciences, University of Szeged, \\ Szeged, Hungary \\ ${ }^{4}$ Institute of Plant Biology, Biological Research Centre Hungarian Academy of Sciences, \\ Szeged, Hungary \\ ${ }^{5}$ Department of Biotechnology, Nanophagetherapy Center, Enviroinvest Corporation, \\ H-Pécs, Hungary
}

(Received: 26 August 2016; revised manuscript received: 22 March 2017; accepted: 10 August 2017)

Petroleum hydrocarbons and derivatives are widespread contaminants in both aquifers and soil, their elimination is in the primary focus of environmental studies. Microorganisms are key components in biological removal of pollutants. Strains capable to utilize hydrocarbons usually appear at the contaminated sites, but their metabolic activities are often restricted by the lack of nutrients and/or they can only utilize one or two components of a mixture. We isolated a novel Rhodococcus sp. MK1 strain capable to degrade the components of diesel oil simultaneously. The draft genome of the strain was determined and besides the chromosome, the presence of one plasmid could be revealed. Numerous routes for oxidation of aliphatic and aromatic compounds were identified. The strain was tested in ex situ applications aiming to compare alternative solutions for microbial degradation of hydrocarbons. The results of bioaugmentation and biostimulation experiments clearly demonstrated that - in certain cases - the indigenous microbial community could be exploited for bioremediation of oil-contaminated soils. Biostimulation seems to be efficient for removal of aged contaminations at lower concentration range, whereas bioaugmentation is necessary for the treatment of freshly and highly polluted sites.

*Corresponding author; E-mail: perei@bio.u-szeged.hu 
Keywords: bioaugmentation, biodegradation, biostimulation, oil decontamination, hydrocarbon bioconversion, utilization, Rhodococcus

\section{Introduction}

Diesel oil consists of various hydrocarbons that have serious toxic effects on living beings [1]. Among the numerous available strategies for removal of hazardous pollutants, the bioremediation methodologies [2, 3] are environmentally sound, reliable, cost-effective, and widely applicable approaches in certain concentration range of contaminants [4-7]. Several types of biotreatments [8] are known, such as composting [9], biopiling [10], biosparging, landfarming, or bioreactor-based conversion of contaminants $[1,5,6,11]$. Depending on the nature and the level of the pollution, either ex situ or in situ treatment can be applied [6]. At and above a certain concentration, the contaminants may become toxic to the organisms, thus the biological approach could not be effective. Application of immobilized cells may lead to a rapid and complete biodegradation owing to the protection of cells against toxic environment by the immobilization matrices $[12,13]$.

The indigenous microorganisms in soils must adapt to the rapidly changing environmental conditions. Some of them might be able to utilize the newly appearing organic compounds provided that the micronutrients are available $[14,15]$. The biostimulation might enhance the natural biotic decomposition by supplementing nutrients and other relevant materials [16, 17], e.g., the addition of biosurfactants to the contaminated sites [18]. However, in many cases, other methods improving the biodegradation efficacy should be included [19]. In such cases, bioaugmentation using preadapted microorganisms might be used to promote the bioconversion rate and yield [5, 14, 20, 21]. An alternative strategy might be the usage of a remediated soil as an "inoculums," since it might contain hydrocarbon-adapted microorganisms for proper biodegradation [22]. However, only a few studies were published on the bioremediation of freshly contaminated site [16] and limited information is available about the usage of previously bioremediated soil to enhance the degradation of hydrocarbons [22].

Bioremediation of hydrocarbon-contaminated sites has been in the focus of numerous studies because of frequent occurrence of oil catastrophes [23] and the daily emitted commercial oily wastes. Both aliphatic and aromatic hydrocarbons can be degraded under either aerobic or anaerobic conditions [6]. The aerobic degradation is more efficient. Most of the hydrocarbons are water-insoluble, which is one of the main reasons that are not easily metabolizable for microorganisms. A frequent mode to enhance the availability of hydrophobic organic compounds is the application of surfactants, which might also be produced by microorganisms $[24,25]$. 
Several species of the genus Rhodococcus were applied in a number of environmental and industrial biotechnology studies because of their ability to degrade a wide range of chemicals [26-30]. Rhodococci are naturally widespread in various contaminated environments due to their wide range of enzymes, surfactants producing capability, and tolerance against several environmental conditions, so they might be commonly used for rehabilitation of soil and aquatic habitats. The presence of exopolysaccharides and mycolates in the cell wall of rhodococci might promote the degradation of pollutants by emulsification of the substrates and protecting the cells [27, 31].

In this study, we present the characterization and draft genome sequence of a novel Rhodococcus sp. MK1 isolate capable to degrade various types of hydrocarbons in diesel oil. The strain was also tested in comparative biostimulation and bioaugmentation experiments performed in laboratory and on field.

\section{Materials and Methods}

\section{Chemicals and contaminated soils}

Summer diesel oil was provided by MOL Group (Hungary), analytical grade dichloromethane (DCM) (>99.8\% purity) was purchased from Sigma-Aldrich. Na-alginate HF 250 was obtained from Protanal (Norway). All other chemicals were derived from standard commercial suppliers (Reanal, VWR International, Merck, Biolab).

The diesel oil-contaminated soil was collected from a contaminated area close to Szeged, Hungary. The contamination had stably existed there for decades (since 1980s). Prior to bioremediation, the total hydrocarbon concentration was $670 \mathrm{mg} / \mathrm{kg}$ soil. "Freshly" contaminated soil was modeled by artificial addition of diesel oil to soil up to total petroleum hydrocarbon $(\mathrm{TPH})=3,480 \mathrm{mg} / \mathrm{kg}$. It was measured after contamination.

\section{Characterization of the hydrocarbon-degrading strain}

The Rhodococcus sp. MK1 strain was isolated from an industrial waste of a chemical company (Nitrokémia Corp., Balatonfüzfó, Hungary) using selective medium containing $1 \%(\mathrm{v} / \mathrm{v})$ diesel oil as carbon source.

Morphological, chemotaxonomical, physiological, and biochemical characterization of the strain was performed. The morphological and chemotaxonomic marker analyses [the fatty acid, mycolic acid patterns were determined by Deutsche Sammlung von Mikroorganismen und Zellkulturen GmbH (DSMZ)] 
were investigated after the cells had been grown on Tryptone Soya agar $(15 \mathrm{~g} / \mathrm{L}$ tryptone, $5 \mathrm{~g} / \mathrm{L}$ soytone, $5 \mathrm{~g} / \mathrm{L}$ sodium chloride, and $15 \mathrm{~g} / \mathrm{L}$ bacto agar). Typical biochemical and physiological characteristics of the strain MK1 were determined by the following assays: oxidase-; catalase tests; urease activity; gelatine-, casein-, Tween 80-, starch hydrolysis tests; nitrate-, nitrite reduction tests, indole production, and methyl-red reactions performed according to Cowan et al. [32]. The growth characteristics were tested in Luria-Bertani broth (LB) medium at different temperatures $\left(4,10,15,20,25,30,35,37,40\right.$, and $\left.42^{\circ} \mathrm{C}\right)$, at different $\mathrm{pH}(5.0,6.0$, 7.0 , and 8.0$)$, and the salt tolerance $[1.0 \%-5.0 \%(\mathrm{w} / \mathrm{v}) \mathrm{NaCl}]$ was determined at $24{ }^{\circ} \mathrm{C}$ for $24 \mathrm{~h}$.

\section{Growth conditions and inoculum preparation}

The strain MK1 was grown in $20 \mathrm{ml} \mathrm{LB}$ medium $(10 \mathrm{~g} / \mathrm{L}$ tryptone, $5 \mathrm{~g} / \mathrm{L}$ yeast extract, and $10 \mathrm{~g} / \mathrm{L} \mathrm{NaCl}$ ) at $24{ }^{\circ} \mathrm{C}$ overnight shaking at $150 \mathrm{rpm}$. Then, the culture was centrifuged (20,200 $\mathrm{rcf}$ for $10 \mathrm{~min})$, and the pellet was suspended to an optical density of 1.0 at $600 \mathrm{~nm}$ in physiological salt solution $(9 \mathrm{~g} / \mathrm{L} \mathrm{NaCl})$. This inoculum was used in subsequent biodegradation experiments.

\section{DNA isolation}

Genomic DNA was isolated with the standard phenol-chloroform method [33] with small modifications. Briefly, cells were cultivated in LB medium overnight. To weaken the cell wall, grown cultures were diluted to $\mathrm{OD}_{600}=$ 0.700 and were supplemented with $1 \mathrm{mg} / \mathrm{ml}$ ampicillin as it was described earlier by Nagy et al. [34]. Cultures were agitated for $2 \mathrm{~h}$ at room temperature in the presence of ampicillin. Pellet of the culture was treated with $50 \mathrm{mg} / \mathrm{ml} \mathrm{lysozyme} \mathrm{at}$ $37{ }^{\circ} \mathrm{C}$. Cells were resuspended in Genomic I. solution $(10 \mathrm{mM} \mathrm{NaCl}, 2 \mathrm{mM}$ Tris $\mathrm{HCl} \mathrm{pH}=8.0,1 \mathrm{mM}$ EDTA, and $0.5 \%$ SDS) and mixed on a Biosan RS-60 rotary shaker (Biosan, Riga, Latvia) for an hour. After proteinase $\mathrm{K}$ and RNase A treatment, the mixture was treated five times with 1:1 phenol:chloroform then precipitated with ice-cold $90 \%(\mathrm{v} / \mathrm{v})$ ethanol in the presence of $300 \mathrm{mM}$ sodium acetate and washed with $70 \%(\mathrm{v} / \mathrm{v})$ ethanol. Purified DNA was dissolved in molecular biology grade water and stored at $-20{ }^{\circ} \mathrm{C}$ until use.

\section{Sequencing $g D N A$}

Genomic DNA was sheared by nebulization according to Roche (Rapid Library Preparation Manual GS FLX+/XL+ version: May 2011). DNA library 
was prepared using the TruSeq DNA PCR-Free LT Library Preparation Kit (Illumina Inc., San Diego, CA, USA) following the instructions of the manufacturer. Paired-end sequencing was carried out on Illumina MiSeq bench top sequencing platform with MiSeq reagent kit v3 $(2 \times 300$ cycles $)$.

\section{Bioinformatics}

Sequencing data obtained in FASTQ format were processed with MIRA 4 assembler [35] running in Debian 7.10 operation system. Quality filtering of reads was automatically performed by the assembler with default options. Read mappings and QC reports were generated by CLC Genomic Workbench 7.5 (QIAGEN Arhus A/S, Arhus, Denmark). All mappings were performed by applying the default parameters. Annotation of the assembled sequences was carried out by the RAST program (version 2.0) [36] with default settings and the classic RAST annotation scheme. Basic Local Alignment Search Tool (https://blast.ncbi.nlm. nih.gov/Blast.cgi) was used for sequence database search.

\section{Deposition of genome-sequencing data}

This whole genome shotgun project has been deposited at DDBJ/ENA/ GenBank under the accession MUBD00000000. The version described in this paper is version MUBD01000000.

\section{Diesel oil degradation in liquid phase and soil at laboratory scale}

The hydrocarbon-degrading capability of the MK1 strain was tested in mineral medium (MM) described in [37] and soil. Diesel oil (1 ml diesel oil was used with $100 \mathrm{ml} \mathrm{MM}$ or $10 \mathrm{~g}$ soil, and there was no other carbon sources) containing MM $(20 \mathrm{ml})$ or soil $\left(50 \mathrm{~g}\right.$, sterilized for $1 \mathrm{~h}$, at $\left.100^{\circ} \mathrm{C}\right)$ was inoculated with $1 \%(\mathrm{v} / \mathrm{v})$ starter culture of the MK1 strain in gas tight serum bottles (volume $50 \mathrm{ml}$ ). The soil water content was adjusted to $20 \%$.

\section{Soil dry matter and water content}

The weight of soil samples was measured and they were dried in a baker at $105{ }^{\circ} \mathrm{C}$ until constant weight. The $20 \%(\mathrm{w} / \mathrm{w})$ water content means $20 \%$ loss in weight during the drying process [38]. 
Experiments with immobilized/entrapped cells

The diesel oil biodegradation efficiency of immobilized cells was also tested in aqueous phase. The method of immobilization into Na-alginate HF 250 was described earlier by Perei et al. [37]. The ratio of $1.5 \%(\mathrm{w} / \mathrm{v})$ Na-alginate solution and cell suspension $\left(10^{6} \mathrm{cell} / \mathrm{ml}\right)$ was $5: 1$. Finally, $20 \mathrm{ml}$ of hydrocarbon containing $\mathrm{MM}$ was inoculated with $1 \mathrm{~g}$ (wet weight) of immobilized cells. The cultures were incubated at room temperature with shaking at $150 \mathrm{rpm}$ for a week. The hydrocarbon content of the samples was extracted with DCM (the volume ratio of the sample and DCM was 1:1). The analysis of the extracts was performed by a gas chromatograph-coupled mass spectrometry (GC-MS) (see below).

\section{Inocula preparation for bioaugmentation processes}

For the field experiments, the MK1 strain was grown in $5 \mathrm{~L}$ fermenters to get large amount of inoculum for bioaugmentation processes. The strain was grown up in $\mathrm{LB}$ medium at $25{ }^{\circ} \mathrm{C}$ for 1 day. The viable cell counts (CFU) were established by plating. The cultures were centrifuged at $13,000 \mathrm{rpm}$ for $10 \mathrm{~min}$ and the pellets were resuspended with proper amount of MM to reach the optical density of 1.0 at $600 \mathrm{~nm}$.

\section{Field experiment}

The field experiment was performed as follows: a $25 \mathrm{~m} \times 35 \mathrm{~m}$ working area was covered with PVC foil for preventing the leakage of hydrocarbons. Five piles (each was $2 \mathrm{~m}^{3}$ ) were created (Table I) from old contaminated soil previously mixed with $5 \mathrm{~g} / \mathrm{kg}$ soil wheat-straw (to lose the soil structure) using a MLT731

Table I. Experimental strategy for comparison of the on site biostimulation and bioaugmentation approaches

\begin{tabular}{|c|c|c|c|c|}
\hline & Old contamination & Old + artificial contamination & Bioaugmentation & \\
\hline Piles & $\mathrm{TPH}=670 \mathrm{mg} / \mathrm{kg}$ & $\mathrm{TPH}=3,480 \mathrm{mg} / \mathrm{kg}$ & MK1 strain & Biostimulation \\
\hline 1 & + & - & - & - \\
\hline 2 & + & - & - & + \\
\hline 3 & + & + & - & + \\
\hline 4 & + & - & + & + \\
\hline 5 & + & + & + & + \\
\hline
\end{tabular}

Note: +: treated; -: untreated; TPH: total petroleum hydrocarbon. 
Manitou compact loader. The distance of the neighboring piles was $30 \mathrm{~cm}$. Holes of 30-35 cm depth and of $5 \mathrm{~cm}$ diameter were drilled at $20 \mathrm{~cm}$ regular distance at the top of the mounds. Diesel oil was added to the piles via these holes (Piles 3, 5). The experimental setup for the piles is presented in Table I. To achieve natural water content (about 20\%), all piles were irrigated with tap water. An amount of $21 \mathrm{~L}$ of mineral salt solution (MM) was added to the Piles $2-5$ for modeling the biostimulation process. The Piles 4 and 5 were inoculated with $5 \times 10^{8} \mathrm{CFU} \mathrm{ml}^{-1}$ MK1, which were previously suspended in $21 \mathrm{~L} \mathrm{MM}\left(5 \times 10^{8}\right.$ cell $/ \mathrm{ml}$ final concentration).

\section{Determination of the hydrocarbon content of soil}

The samples were taken from the piles by 3 weeks in a total 9-week period. Each sample was a mixture of 100-100 g of soils collected from three different areas/depth of a pile. This step was critical because of the heterogeneity of contamination [39]. About $10 \mathrm{~g}$ soil from each homogenized sample was used for the determination of hydrocarbon content in three replicates. The hydrocarbons were extracted with DCM [1:1 (w:v) ratio] and $1 \mu \mathrm{l}$ from the organic phase was injected into a gas chromatograph. The hydrocarbon concentrations were calculated from the peak areas. The analytical procedure was validated by comparing the theoretical and experimentally measured hydrocarbon concentrations in soils freshly contaminated with diesel oil (the relationship was linear with the range of $0-10.000 \mathrm{mg} / \mathrm{kg}$ range with a square of the correlation coefficient: $r^{2}=0.9988$ ). Each sample was measured in triplicates.

\section{Gas chromatography (GC) analysis}

Diesel oil contents of the samples were measured on Agilent $6890 \mathrm{GC}$ (Agilent Technologies Inc., Santa Clara, CA, USA) coupled with an Agilent $5975 \mathrm{C}$ EI-simple quadrupole mass spectrometer. GC was equipped with $30 \mathrm{~m} \times 250 \mu \mathrm{m} \times 25 \mu \mathrm{m}$ HP-5MS capillary column (Agilent Technologies Inc., Cat. No.: 19091S-433). Samples of $1 \mu$ l volume were injected with an Agilent $7683 \mathrm{~B}$ autosampler unit. Split ratio was set to $15: 1$ and the column flow rate was $1.2 \mathrm{ml} / \mathrm{min}$. Oven program was as follows: initial temperature was set to $65^{\circ} \mathrm{C}$ and held for 4 min subsequently increasing the temperature until $290^{\circ} \mathrm{C}$ by $15^{\circ} \mathrm{C} / \mathrm{min}$. Final temperature was kept for $5 \mathrm{~min}$. Ionization energy was $70 \mathrm{eV}$. Data were obtained with single ion monitoring following the most abundant ions in the diesel oil main components $(\mathrm{m} / \mathrm{z}=57$ and 71$)$. Samples were quantified by considering summed peak area of the chromatogram. 
The respiration activities were determined according to the protocol described in [51].

\section{Data analysis}

Each experiment was repeated thrice. The bioconversion percentage of diesel oil degradation was calculated by the following expression:

$$
[(\operatorname{Control}(\text { cell free })-\text { Treated }) / \operatorname{Control}(\text { cell free })] \times 100
$$

\section{Results and Discussion}

\section{Strain characterization}

The MK1 strain is a Gram-positive, aerobic bacterium with oxidase-, urease-, catalase- and protease activity; starch was not hydrolyzed and there was no sign of nitrate-, nitrite-reduction activity, acid-fast. The MK1 strain was grown at temperatures ranging from 4 to $33{ }^{\circ} \mathrm{C}$; however, the optimal growth was observed at $25^{\circ} \mathrm{C}$. The cells could tolerate $5 \%(\mathrm{w} / \mathrm{v})$ salt concentration. The $\mathrm{pH}$ range for growth was $6.0-8.0$, but optimum was at $\mathrm{pH}=7.0$. The major fatty acids $(1 \%-5 \%)$ of the cells were $\mathrm{C}_{16: 0}(>30 \%), \mathrm{C}_{16: 1}(15 \%-30 \%), \mathrm{C}_{18: 0}(15 \%-30 \%), \mathrm{C}_{18: 1}(>30 \%)$, and $18-\mathrm{Me}(>30 \%)$. One of the main characteristics for rhodococci is the mycolic acid content. In the MK1 strain, mycolic acids were built up with 32-44 carbon atoms in our isolate. The DNA G + C content of the MK1 strain was $63 \mathrm{~mol} \%$. According to the classical taxonomical classification, the strain was identified as Rhodococcus erythropolis MK1 (DSMZ GmbH).

Sequencing Rhodococcus sp. MK1 genome

The whole genome sequencing of the MK1 strain resulted in 978,788 paired-end reads. About $97.35 \%$ of the reads were between 299-301 bp in length. About $96.75 \%$ of the reads had an average Phred score above 20 and the ratio of ambiguous base containing sequences was $0.07 \%$.

The genome sequence of the strain has been deposited in the DDBJ/ENA/ GenBank. The genome comparisons revealed that the closest reference genome was the $R$. erythropolis CCM2595 (Bioproject PRJNA81583) genome with $87.3 \%$ symmetrical identity value (SIV), the closest complete genome was the genome of 
Rhodococcus sp. BH4 (Bioproject: PRJNA313101, 88.7\% SIV), whereas the closest draft genome was that of Rhodococcus qingshengii CW25 (Bioproject: PRJNA316739, 94.4\% SIV). According to these comparisons, the GenBank classified our strain as $R$. qingshengii MK1. Still, there is no fully assembled $R$. qingshengii genome available. Nevertheless, the reads of the MK1 were mapped onto the $R$. qingshengii CW25 and $R$. qingshengii CS98 contigs and $92.8 \%$ and $90.0 \%$ of the reads could be mapped onto their contigs, respectively.

However, four fully sequenced genomes of $R$. erythropolis are available in the database [40-43]. R. erythropolis CCM2595 has one, the other three strains (BG43, R138, and PR4) possess three plasmids of 3.7-478 $\mathrm{kb}$ size (Table II). Moreover, three other plasmids have been fully sequenced (without the chromosome) [44-46]. Mapping the reads onto the existing genomes resulted 30 times average coverage and $87 \%-88 \%$ of the reads were mapped onto all chromosomes. This is in concordance with our presumption of close relationship between MK1 and the other four strains. On the other hand, less than $0.6 \%$ of the reads could be mapped onto the 12 plasmid sequences. Harboring multiple plasmids of a variety of size in either linear or circular form in within the same cell is a common feature among rhodococci (Table II) [40, 47].

The assembly of the reads of the MK1 genome with MIRA 4 resulted in 40 contigs, the total size of the contigs was $6,469,205 \mathrm{bp}$. GC content was $62.5 \%$.

Table II. Mapping statistics of the reads derived from the genome sequencing of the MK1 strain onto the other known $R$. erythropolis genetic elements derived from complete genome sequencing

\begin{tabular}{lclrr}
\hline Organism & Molecule name & \multicolumn{1}{c}{ Type } & Length (bp) & Reads mapped (\%) \\
\hline R. erythropolis CCM2595 & & Chromosome & $6,281,198$ & 87.43 \\
& pRECF1 & Plasmid & 90,223 & 0.33 \\
R. erythropolis BG43 & - & Chromosome & $6,334,075$ & 87.81 \\
& pRLCBG43 & Plasmid & 240,129 & 0.19 \\
& pRLLBG43 & Plasmid & 261,537 & 0.59 \\
& pRSLBG43 & Plasmid & 29,464 & 0 \\
R. erythropolis R138 & - & Chromosome & $6,236,682$ & 87.45 \\
& pCRE138 & Plasmid & 477,915 & 0.56 \\
& pLRE138 & Plasmid & 91,729 & 0.16 \\
& & Chromosome & $6,516,310$ & 87.27 \\
& pREC1 & Plasmid & 104,014 & 0.09 \\
& pREC2 & Plasmid & 3,637 & 0 \\
& pREL1 & Plasmid & 271,577 & 0.23 \\
& pDB2 & Plasmid & 210,205 & 0.15 \\
& pRE8424 & Plasmid & 5,987 & 0 \\
& pFAJ2600 & Plasmid & 5,936 & 0 \\
\hline
\end{tabular}


Based on RAST results, 6,252 open reading frames (ORF) were identified in the assembled genomes. About $36 \%$ of the annotated features could be metabolically classified by RAST. The metabolic distribution of the genes is shown in Figure 1 .

We mapped the reads that are not matching to the reference genomes on each individual contig. Out of these, $18.31 \%$ of the reads were mapped on a 105,331-bp long sequence (contig 20) and the read numbers were evenly distributed along the sequence. Average coverage was 46.3. BLASTn analyses against the nonredundant nucleotide database revealed that this contig shares partial sequence identity with distinct rhodococcus plasmids. The annotation process disclosed 118 ORFs coding DNA-modifying enzymes, integrase, and mobile elements, which are common among Rhodococcus plasmids. It also has its own parAB genes, which are responsible for plasmid partitioning. Based on these results, we assume that contig 20 can be a novel Rhodococcus plasmid. Around $58 \%$ of the ORFs are hypothetical; however, contig 20 contains genes encoding mercury and cadmiumresistance proteins, glucoamylase, glucose-6-phosphate dehydrogenase, and highaffinity carbon uptake protein, as well. In addition, it does not contain any genes coding for hydrocarbon biodegradation, all of these enzymes seem to be localized on the chromosome.

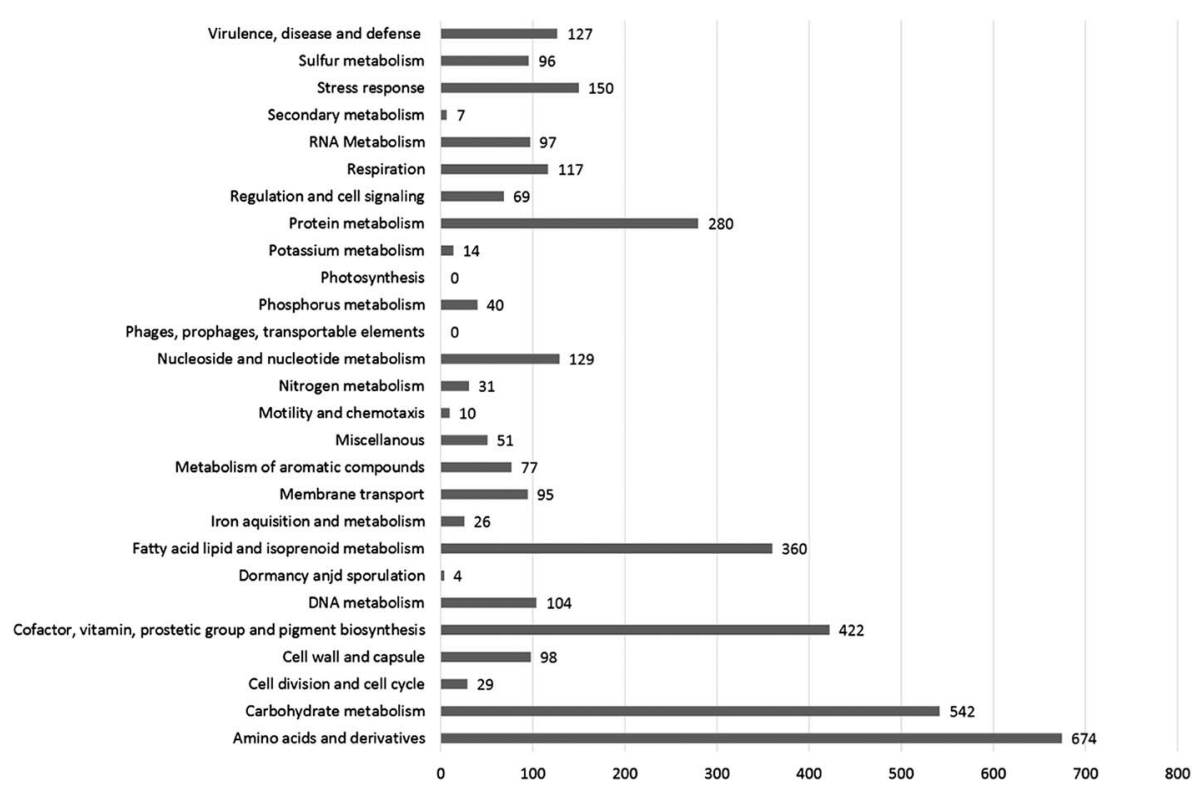

Figure 1. Features in subsystems in Rhodococcus sp. MK1. The numbers on the figure represent the number of genes involved in the corresponding metabolic pathways 
Genes involved in hydrocarbon oxidation

The major components of diesel oil are alkanes. Oxidation of these compounds is the key step of their bioconversion. Bacteria have evolved a number of oxygenase enzymes catalyzing this crucial step on alkanes of various chain lengths [48].

In the genome of the MK1 strain, five genes coding for alkane-1monooxygenase (AlkB) enzymes have been found. These are non-hem iron proteins integrated into the cell membrane. Usually, AlkB enzymes use rubredoxin as electron carrier in the oxidation reaction, but in our case, only two AlkB genes are associated with rubredoxin and tet $R$ type regulator genes. The latter might act as transcriptional regulator. Rubredoxin reductase is present only in one $A l k B$ gene cluster. In our recent study, we have shown that only those $A l k B$ genes have highly elevated transcription in the presence of alkanes, which have rubredoxin and tet $R$ regulator genes in their proximity in R. erythropolis PR4 [49], thus these can be the key enzymes in medium chain alkane oxidation.

In $R$. erythropolis PR4, there are two paralogues of cyp 153 genes encoding cytochrome P450 enzymes, which are responsible for oxidation of short chain alkanes [40, 48-50]. On the contrary, the MK1 strain does not possess a copy of the gene, since it lacks the pREL1-type plasmid, which encodes the cyp153 genes. CYP153 enzymes are usually responsible for oxidation of short chain alkanes. Apparently, the strain MK1 could utilize short chain alkanes only in the presence of longer alkanes (data not shown), which might indicate the role of other enzymes, such as AlkB [48]. There are 11 other cytochrome P450 proteins encoded in the MK1 genome alongside numerous other genes coding for oxygenase likely catalyzing the oxidation of a variety of aliphatic and aromatic compounds.

Based on RAST SEED viewer, there are 77 genes belonging to the subsystem for aromatic compound metabolism (Figure 1). Twelve genes participate in the peripheral and 57 genes in the central catabolic pathway. Eight genes are related to the metabolism of aromatics but cannot be classified in any of the two subcategories above.

Biodegradation of diesel oil in liquid phase and soil under laboratory conditions

In the preliminary study, the diesel oil degradation activity of the MK1 strain was tested by monitoring of cell respiration activity in liquid culture for 1 week [51]. Respiration of the cells was intensive, almost all of the available oxygen was consumed and large amount of carbon dioxide was produced. These results and genome data suggest that the MK1 strain can efficiently convert at least one component of diesel oil contaminations. 
The diesel oil concentration was followed by GC-MS to evaluate the hydrocarbon consumption. In liquid phase, both free and immobilized cells were applied. Without immobilization, almost $70 \%$ of the diesel oil was removed by cells as compared with cell-free control samples, while a lower degradation rate was obtained in the case of immobilized cells (Figure 2). This latter result might be surprising, since the immobilization of cells is expected to have a protective effect, which usually improves the bioremediation efficacy. Presumably, the cell wallbound surfactants of the strain MK1 entrapped were hardly able to interact with the hydrophobic components floating on water surface leading to a reduction in hydrocarbon degradation. This coincides with the observation, that in a biphasic liquid (oil - water after stopping the shaking) culture, the cells were strongly attached to the upper organic phase, whereas the aqueous phase remained clear (data not shown).

A spectacular change in practically all peak height could be observed after 1 week of cell growth on diesel oil (Figure 3A and B). Apparently, the height (area) of all peaks decreased simultaneously, indicating the broad substrate specificity of the strain. Four chemically distinct components of diesel oil (xylene, n-nonane, n-hexadecane and 2,6,10-trimethyltetradecane, indicated by arrows in Figure $3 \mathrm{~A}$ and $\mathrm{B}$ ) were chosen and their biodegradation rate was quantified (Figure 4). The bioconversion rates were calculated from the consumption of substrates related to their initial concentrations. It can be clearly seen that each compound could be converted by the strain MK1, their quantities were dropped to $30 \%-40 \%$ of the initial concentration in a week. This feature is an important advantage in a comparison with Alcanivorax borkumensis, which is considered to be one of the main oil degraders, however, it predominantly degrades n-alkanes only $[52,53]$.

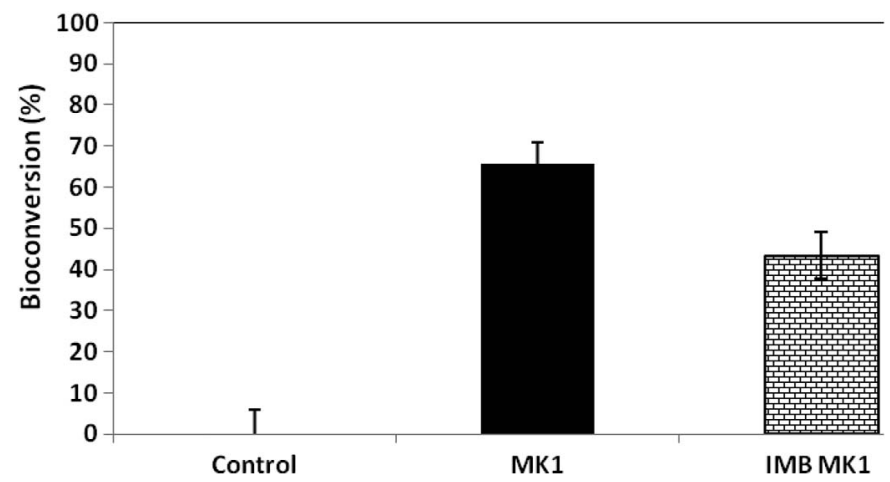

Figure 2. Bioconversion (\%) of diesel oil in minimal medium using free and entrapped cells. Control: cell-free, MK1: sample containing freely moveable cells, IMB MK1: immobilized MK1 

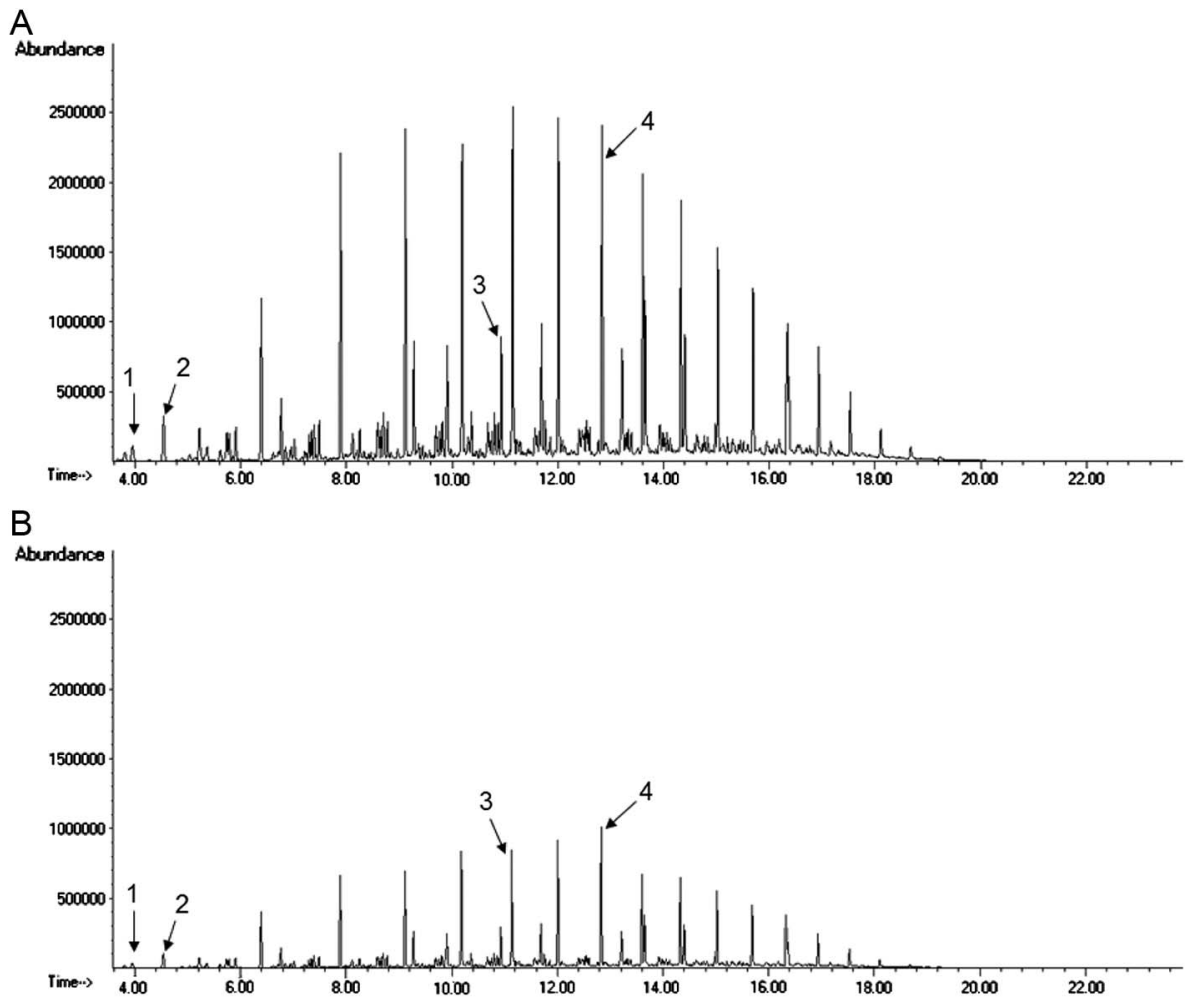

Figure 3. Chromatogram of cell free control (A) and MK1 culture (B) grown on diesel oil. The arrows indicate the following components, which were further analyzed (see Figure 4). 1: p-xylene (RT: $3.96 \mathrm{~min}$ ), 2: n-nonane (RT: $4.54 \mathrm{~min}$ ), 3: 2,6,10-trimethyltetradecane (RT: $11.69 \mathrm{~min}$ ), and 4: n-hexadecane (RT: $12.83 \mathrm{~min}$ )

The hydrocarbon-degrading activity of the MK1 strain was also characterized in contaminated soil under laboratory conditions. The soil was supplemented with $1 \%(\mathrm{w} / \mathrm{v})$ diesel oil; the biodegradation was monitored for 1 week by measuring the TPH concentrations. The efficacy of diesel oil biodegradation in soil $(66 \%)$ was similar to the values obtained in the liquid culture.

\section{Field application}

To test our strain in real ex situ bioremediation technology, biopiles were constructed using "old" and artificially polluted soil. The experimental design can be seen in Table I. The Piles 1, 2, and 4 were heaped from old contaminated soils. The diesel oil was released into the field more than 20 years ago and its 


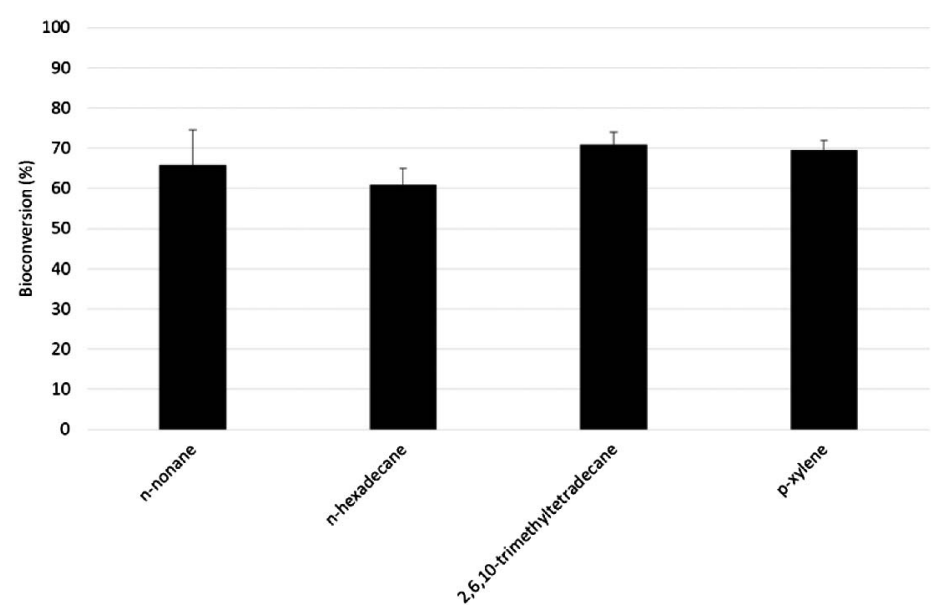

Figure 4. The bioconversion of individual compounds indicated in Figure 3

concentration was $671 \mathrm{mg} / \mathrm{kg}$ in the soil (old contaminated soil) at the beginning of the experiments. Piles 3 and 5 heaped from old contaminated soil polluted additionally with "fresh" diesel oil (referred as artificially or freshly contaminated soil), where the concentration of the pollutant was five times higher $(3,480 \mathrm{mg} / \mathrm{kg}$ soil) than in the old contaminated ones. These piles will be referred as freshly contaminated sites.

Neither nutrients nor MK1 was added to the control pile (Pile 1). The indigenous microflora was stimulated using mineral solution (MM) in the biostimulated piles (Piles 2-5). The strain MK1 was inoculated into the bioaugmented piles (Piles 4 and 5). Biodegradation processes were followed by measuring hydrocarbon concentration.

There were no changes in the control pile (Figure 5A, Pile 1) in 9 weeks. However, the quantity of the hydrocarbons rapidly decreased in the biostimulated pile (Figure 5A, Pile 2) containing exclusively old contamination. It might be concluded that the contaminated soil might have been depleted in components essential for microbial life, since the microbial activity could be simply stimulated by supplementing the Pile 2 with minerals. Comparing the results of the biostimulation (Figure 5A, Pile 2) and bioaugmentation (Figure 5A, Pile 4) experiments, no significant differences between the degradation rates in Piles 2 and 4 could be observed. According to these results, it is presumable that inactive local microflora has accumulated at the old contamination, which could be activated by providing minerals. In other words, the MK1 strain could not further accelerate the degradation of aged pollutants in the concentration range applied. 

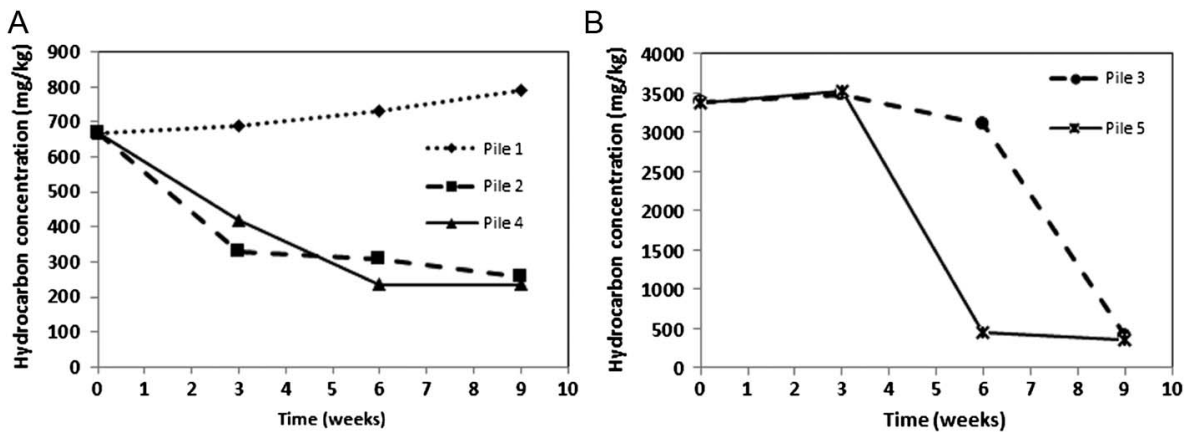

Figure 5. $\mathrm{TPH}$ in piles containing old (A) $(\mathrm{TPH}=670 \mathrm{mg} / \mathrm{kg})$ and fresh $(\mathrm{B})(\mathrm{TPH}=3480 \mathrm{mg} / \mathrm{kg})$ contamination during bioremediation. Pile 1: diamond, dotted (A); Pile 2: square, dashed (A); Pile 3: circle, dashed (B); Pile 4: triangle, continuous (A); Pile 5: asterisk continuous (B). The curves illustrate representative data of the experiments. In each case, in each sample, similar tendencies were observed

Two piles were used to model fresh contamination in field experiments (Figure 5B). The old contaminated soil was used to heap these piles (Piles 3, 5) that have been polluted artificially/freshly with diesel oil. Nutrients were added to all of these piles, while the Pile 5 was bioaugmented with the strain MK1.

The biostimulation and bioaugmentation approaches were compared for soils freshly polluted with diesel oil at much higher concentration. It can be seen in Figure 5 that the indigenous microorganisms in Pile 3 had a longer lag period in spite of the fact that the pile was supplemented with nutrients. Biodegradation of hydrocarbons was visible after 3 weeks in the case of the bioaugmented Pile 5. The degradation rate was apparently accelerated in the biostimulated pile (Pile 3 ) after 6 weeks. At the end of the experiment ( 9 weeks), the concentration of hydrocarbons was less than the original concentration of the old contamination in both piles. Consequently, the fresh contamination could be apparently removed in 3 months by stimulating local microorganisms; however, a much faster degradation could be achieved by applying bioaugmentation. Nevertheless, the final bioconversion yields were approximately the same for both approaches. Thus, biostimulation is cheaper while bioaugmentation is faster technique for bioremediation of fresh pollutants.

\section{Conclusions}

The strain MK1, isolated from an industrially contaminated site, was identified on the basis of morphological, chemotaxonomical, physiological, and biochemical properties as $R$. erythropolis MK1. Comparison of the draft genome 
sequence of the MK1 strain to the genomes in the databases revealed the genome of $R$. erythropolis CCM2595 and $R$. qingshengii CW25 as the closest species reference genome and closest draft genome, respectively. Thus, the strain appears in the genome databases as $R$. qingshengii MK1. In the MK1 genome, numerous genes coding for enzymes likely participate in hydrocarbon biodegradation. Moreover, a novel extrachromosomal element was likely identified. The $R$. erythropolis MK1 proved to be very adaptive and it could efficiently decompose numerous components of diesel oil in liquid or soil phase at laboratory conditions.

Little is known about the hydrocarbon-degradation activity of the immobilized rhodococci. It was shown that entrapment of the strain MK1 led to reduced degradation ability indicating that the bacterium had cell wall-bound surfactant. The alginate layer prevented the direct connection of the cells to the hydrocarbons and in the absence of "mobile" surfactants, the substrates could not be efficiently emulsified.

Accidental oil leaks/spills are common during the transportation of fuels, which require a rapid and clean pollution removal process especially close to dwelling places.

The processes developed in laboratory sometimes do not work well in field under uncontrolled conditions. The data obtained from the comparison of ex situ bioaugmentation and biostimulation experiments suggested that the indigenous strains could be efficiently activated for bioremediation of oil contaminated soils in certain cases. Biostimulation might be sufficient for old contaminations, whereas bioaugmentation is necessary for freshly and highly polluted sites.

\section{Acknowledgements}

This research was realized in the frames of TÁMOP 4.2.4.A/2-11-1-2012001 "National Excellence Program - Elaborating and operating an inland student and researcher personal support system convergence program." The project was subsidized by the European Union and cofinanced by the "European Social Fund" (grant agreement no. TÁMOP-4.1.1.C-12/1/KONV-2012-0012) and by the Norway Grant (grant agreement no. HU09-0044-A1-2013).

\section{Conflict of Interest}

The authors declare no conflict of interest present in this work. 


\section{References}

1. Namkoong, W., Hwang, E. Y., Park, J. S., Choi, J. Y.: Bioremediation of dieselcontaminated soil with composting. Environ Pollut 119, 23-31 (2002).

2. Juwarkar, A., Singh, S. K., Mudhoo, A.: A comprehensive overview of elements in bioremediation. Rev Environ Sci Biotech 9, 215-288 (2010).

3. Ward, O. P., Singh, A., Van Hamme, J. D., Voordouw, G.: Petroleum microbiology. In Schmidt, T., Schaechter, M. (eds): Topics in Ecological and Environmental Microbiology. Academic Press, San Diego, 2012.

4. Bartha, R.: Biotechnology of petroleum pollutant biodegradation. Microb Ecol 12, 155-172 (1986).

5. Balba, M., Al-Awadhi, N., Al-Daher, R.: Bioremediation of oil-contaminated soil: Microbiological methods for feasibility assessment and field evaluation. J Microbial Methods 32, 155-164 (1998).

6. Hamme, J. D., Van Singh, A., Ward, O. P.: Recent advances in petroleum microbiology. Microbiol Mol Biol Rev 67, 503-549 (2003).

7. Bento, F. M., Camargo, F. O., Okeke, B. C., Frankenberger, W. T.: Comparative bioremediation of soils contaminated with diesel oil by natural attenuation, biostimulation and bioaugmentation. Bioresour Technol 96, 1049-1055 (2005).

8. Aleer, S., Adetutu, E. M., Makadia, T. H., Patil, S., Ball, A. S.: Harnessing the hydrocarbondegrading potential of contaminated soils for the bioremediation of waste engine oil. Water Air Soil Pollut 218, 121-130 (2010).

9. Tomati, U., Galli, E., Pasetti, L., Volterra, E.: Bioremediation of olive-mill wastewaters by composting. Waste Manag Res 13, 509-518 (1995).

10. Baeta-Hall, L., Céu Sàágua, M., Lourdes Bartolomeu, M., Anselmo, A. M., Fernanda Rosa, M.: Bio-degradation of olive oil husks in composting aerated piles. Bioresour Technol 96, 69-78 (2005).

11. Robles-González, I. V., Fava, F., Poggi-Varaldo, H. M.: A review on slurry bioreactors for bioremediation of soils and sediments. Microb Cell Fact 7, 5 (2008).

12. Lin, J. E., Wang, H. Y.: Use of co-immobilised biological systems to degrade toxic organic compounds. Biotechnol Bioeng 38, 273-279 (1991).

13. Pritchard, P. H.: Use of inoculation in bioremediation. Curr Opin Biotechnol 3, 232-243 (1992).

14. Mishra, S., Jyot, J., Kuhad, R. C., Lal, B.: Evaluation of inoculum addition to stimulate in situ bioremediation of oily-sludge contaminated soil. Appl Environ Microbiol 67, 1675-1681 (2001).

15. Vasudevan, N., Rajaram, P.: Bioremediation of oil sludge-contaminated soil. Environ Int 26, 409-411 (2001).

16. Nikolopoulou, M., Kalogerakis, N.: Biostimulation strategies for fresh and chronically polluted marine environments with petroleum hydrocarbons. J Chem Technol Biotechnol 84, 802-807 (2009).

17. Sarkar, D., Ferguson, M., Datta, R., Birnbaum, S.: Bioremediation of petroleum hydrocarbons in contaminated soils: Comparison of biosolids addition, carbon supplementation, and monitored natural attenuation. Environ Pollut 136, 187-195 (2005). 
18. Lin, T. C., Pan, P. T., Young, C. C., Chang, J. S., Chang, T. C., Cheng, S. S.: Evaluation of the optimal strategy for ex situ bioremediation of diesel oil-contaminated soil. Environ Sci Pollut Res Int 18, 1487-1496 (2011).

19. Singer, A. C., Van der Gast, C. J., Thompson, I. P.: Perspectives and vision for strain selection in bioaugmentation. Trends Biotechnol 23, 74-77 (2005).

20. Barathi, S., Vasudevan, N.: Bioremediation of crude oil contaminated soil by bioaugmentation of Pseudomonas fluorescens NS1. J Enviro Sci Health 38, 1857-1866 (2003).

21. El Fantroussi, S., Agathos, S. N.: Is bioaugmentation a feasible strategy for pollutant removal and site remediation? Curr Opin Microbiol 8, 268-275 (2005).

22. Makadia, T. H., Adetutu, E. M., Simons, K. L., Jardine, D., Sheppard, P. J., Ball, A. S.: Re-use of remediated soils for the bioremediation of waste oil sludge. J Environ Manage 92, 866-871 (2011).

23. Kerr, R., Kintisch, E., Stokstad, E.: Will deepwater horizon set a new standard for catastrophe? Science 328, 674-675 (2010).

24. Satpute, S. K., Banat, I. M., Dhakephalkar, P. K., Banpurkar, A. G., Chpade, B. A.: Biosurfactants, bioemulsifiers and exopolysaccharides from marine microorganisms. Biotechnol Adv 28, 436-450 (2010).

25. Mnif, S., Chamkha, M., Labat, M., Sayadi, S.: Simultaneous hydrocarbon biodegradation and biosurfactant production by oilfield-selected bacteria. J Appl Microbiol 111, 525-536 (2011).

26. Bell, K. S., Philp, J. C., Christofi, N.: The genus Rhodococcus. J Appl Microbiol 85, 195-210 (1998).

27. De Carvalho, C. C. C. R., Da Fonseca, M. M. R.: Degradation of hydrocarbons and alcohols at different temperatures and salinities by Rhodococcus erythropolis DCL14. FEMS Microbiol Ecol 51, 389-399 (2005).

28. Goswami, M., Shivaran, N., Singh, R. P.: Microbial metabolism of 2-chlorophenol, phenol and q-cresol by Rhodococcus erythropolis M1 in coculture with Pseudomonas fluorescens P1. Microbiol Res 160, 101-109 (2005).

29. Lee, E. H., Kim, J., Cho, K.-S., Ahn, Y. G., Hwang, G. S.: Degradation of hexane and other recalcitrant hydrocarbons by a novel isolate, Rhodococcus erythropolis EH831. Environ Sci Pollut Res Int 17, 64-77 (2010).

30. Paisio, C. E., Talano, M. A., González, P. S., Busto, V. D., Talou, J. R., Agostini, E.: Isolation and characterization of a Rhodococcus strain with phenol-degrading ability and its potential use for tannery effluent biotreatment. Environ Sci Pollut Res Int 19, 3430-3439 (2012).

31. De Carvalho, C. C. C. R., Da Fonseca, M. M. R.: The remarkable Rhodococcus erythropolis. Appl Microbiol Biotechnol 67, 715-726 (2005).

32. Cowan, S. T., Steel, K. J., Barrow, G. I., Feltham, R. K. A.: Cowan and Steel's Manual for the Identification of Medical Bacteria, $3^{\text {rd }}$ Edition. Cambridge University Press, Cambridge, 2004, pp. 21-49.

33. Sambrook, J., Fritsch, E. F., Maniatis, T.: Molecular Cloning: A Laboratory Manual, $2^{\text {nd }}$ Edition. Cold Spring Harbor Laboratory Press, Cold Spring Harbor, 1, 1989, pp. 25-27.

34. Nagy, I., Schoofs, G., De Schrijver, A., Vanderleyden, J., De Mot, R.: New method for RNA isolation from actinomycetes: Application to the transcriptional analysis of the alcohol oxidoreductase gene theE in Rhodococcus and Mycobacterium. Lett Appl Microbiol 25, 75-79 (1997). 
35. Chevreux, B., Wetter, T., Suhai, S.: Genome sequence assembly using trace signals and additional sequence information. Comput Sci Biol 99, 45-56 (1999).

36. Overbeek, R., Olson, R., Pusch, G. D., Olsen, G. J., Davis, J. J., Disz, T., Edwards, R. A., Gerdes, S., Parrello, B., Shukla, M., Vonstein, V., Wattam, A. R., Xia, F., Stevens, R.: The SEED and the Rapid Annotation of microbial genomes using Subsystems Technology (RAST). Nucleic Acids Res 42, D206-D214 (2014).

37. Perei, K., Rákhely, G., Kiss, I., Polyák, B., Kovács, K. L.: Biodegradation of sulfanilic acid by Pseudomonas paucimobilis. Appl Microbiol Biotechnol 55, 101-107 (2001).

38. Schinner, F., Öhlinger, R., Kandeler, E., Margesin, R.: Methods in Soil Biology. SpringerVerlag, Berlin/Heidelberg, 385, 1996, p. 385.

39. Rogers, K. A., Meyers, R. A.: Encyclopedia of Environmental Analysis and Remediation. Wiley, New York, 8, 1998, pp. 3786-3789.

40. Sekine, M., Tanikawa, S., Omata, S., Saito, M., Fujisawa, T., Tsukatani, N., Tajima, T., Sekigawa, T., Kosugi, H., Matsuo, Y., Nishiko, R., Imamura, K., Ito, M., Narita, H., Tago, S., Fujita, N., Harayama, S.: Sequence analysis of three plasmids harboured in Rhodococcus erythropolis strain PR4. Environ Microbiol 8, 334-346 (2006).

41. Kwasiborski, A., Mondy, S., Beury-Cirou, A., Faure, D.: Genome sequence of the quorumquenching Rhodococcus erythropolis strain R138. Genome Announc 2, e00224-14 (2014).

42. Strnad, H., Patek, M., Fousek, J., Szokol, J., Ulbrich, P., Nesvera, J., Paces, V., Vlcek, C.: Genome sequence of Rhodococcus erythropolis strain CCM2595, a phenol derivativedegrading bacterium. Genome Announc 2, e00208-14 (2014).

43. Muller, C., Birmes, F.S., Niewerth, H., Fetzner, S.: Conversion of the Pseudomonas aeruginosa quinolone signal and related alkyl hydroxyquinolines by Rhodococcus $\mathrm{sp}$. strain BG43. Appl Environ Microbiol 80, 7266-7274 (2014).

44. Stecker, C., Johann, A., Herzberg, C., Averhoff, B., Gottschalk, G.: Complete nucleotide sequence and genetic organization of the 210-kilobase linear plasmid of Rhodococcus erythropolis BD2. J Bacteriol 185, 5269-5274 (2003).

45. Nakashima, N., Tamura, T.: Isolation and characterization of a rolling-circle-type plasmid from Rhodococcus erythropolis and application of the plasmid to multiple-recombinantprotein expression. Appl Environ Microbiol 70, 5557-5568 (2004).

46. De Mot, R., Nagy, I., De Schrijver, A., Pattanapipitpaisal, P., Schoofs, G., Vanderleyden, J.: Structural analysis of the $6 \mathrm{~kb}$ cryptic plasmid pFAJ2600 from Rhodococcus erythropolis NI86/21 and construction of Escherichia coli-Rhodococcus shuttle vectors. Microbiology 143, 3137-3147 (1997).

47. Alvarez, H. M.: Biology of Rhodococcus. Springer, Berlin/Heidelberg, 2010, pp. 77-79.

48. van Beilen, J. B., van Funhoff, E. G.: Alkane hydroxylases involved in microbial alkane degradation. Appl Microbiol Biotechnol 74, 13-21 (2007).

49. Laczi, K., Kis, Á., Horváth, B., Maróti, G., Hegedüs, B., Perei, K., Rákhely, G.: Metabolic responses of Rhodococcus erythropolis PR4 grown on diesel oil and various hydrocarbons. Appl Microbiol Biotechnol 99, 9745-9759 (2015).

50. Wang, W., Shao, Z.: Enzymes and genes involved in aerobic alkane degradation. Front Microbiol 4, 116 (2013).

51. Kis, Á., Laczi, K., Hajdú, A., Szilágyi, Á., Rákhely, G., Perei, K.: Efficient removal of unctuous wastes from wastewater. Int J Biosci Biochem Bioinf 3, 395-397 (2013). 
52. Sabirova, J. S., Becker, A., Lünsdorf, H., Nicaud, J.-M., Timmis, K. N., Golyshin, P. N.: Transcriptional profiling of the marine oil-degrading bacterium Alcanivorax borkumensis during growth on n-alkanes: Transcriptomic responses of Alcanivorax borkumensis. FEMS Microbiol Lett 319, 160-168 (2011).

53. Naether, D. J., Slawtschew, S., Stasik, S., Engel, M., Olzog, M., Wick, L. Y., Timmis, K. N., Heipieper, H. J.: Adaptation of the hydrocarbonoclastic bacterium Alcanivorax borkumensis SK2 to alkanes and toxic organic compounds: A physiological and transcriptomic approach. Appl Environ Microbiol 79, 4282-4293 (2013). 